\title{
Mercury and Chlorinated Pesticides on the Highest Level of the Food Web as Exemplified by Herring from the Southern Baltic and African Penguins from the Zoo
}

\author{
Lucyna Falkowska • Andrzej R. Reindl • \\ Emilia Szumiło • Justyna Kwaśniak • \\ Marta Staniszewska • Magdalena Beldowska • \\ Anita Lewandowska • Izabela Krause
}

Received: 24 November 2012 / Accepted: 28 March 2013 /Published online: 19 April 2013

(C) The Author(s) 2013. This article is published with open access at Springerlink.com

\begin{abstract}
Aquatic birds are often used as a health indicator of the marine ecosystem. African penguins living in the zoo make good research material as they form a link between the marine and the terrestrial ecosystem in terms of xenobiotic circulation. Tests were performed on whole herring - the food of the penguins - as well as on bird muscle, liver, brain, eggs, feathers and guano in order to determine total mercury, aldrin, dieldrin, endrin, isodrin, endosulfan isomers, endosulfan sulfate, methoxychlor, dichlorodiphenyltrichloroethane (DDT) and its metabolites. In herring and penguin, the tests did not show the presence of $\beta$-endosulfan, endosulfan sulfate, aldrin and isodrin. It was shown that penguins absorb about $36.8 \mu \mathrm{g}$ of organochlorine pesticides and $4.6 \mu \mathrm{g}$ of mercury with their food on a daily basis. Xenobiotics accumulate mostly in the liver, from where they are transported to the muscles and the brain, where
\end{abstract}

L. Falkowska • A. R. Reindl $(\bowtie) \cdot$ E. Szumiło

J. Kwaśniak • M. Staniszewska $\cdot$ M. Bełdowska

A. Lewandowska

Department of Marine Chemistry and Environmental

Protection, Faculty of Oceanography and Geography,

University of Gdańsk,

Al. Pilsudskiego 46,

81-387 Gdynia, Poland

e-mail: andrzej.reindl@ug.edu.pl

I. Krause

Municipal Zoological Garden,

ul Karwieńska 3,

80-001 Gdańsk, Poland the highest bioaccumulation factor is reached by endrin and pp'-DDT. Conceivably, the older the penguin, the higher is the concentration level of pesticides in its liver and brain. Molting was found to be the most effective way of eliminating mercury, dieldrin and methoxychlor from the system. Insecticides, such as DDT and its metabolites, were removed most effectively by females through laying of eggs. The standard four eggs laid within a year may have contained up to $20 \%$ of the total amount of pesticides which had been absorbed with food, but no more than $5 \%$ of mercury.

Keywords Mercury · Persistent organic pollutants . Clupea harengus $\cdot$ Spheniscus demersus .

Southern Baltic

\section{Introduction}

Mercury and pesticides are present in all elements of the terrestrial and marine environment. Organochlorine compounds created by humans are durable and resilient to biodegradation, demonstrate durability during photodegradation and, when used as pesticides, exhibit toxic properties as a direct result. However, what is very useful in fighting pests in crops has a negative impact on other animals and people (Ebadi et al. 2005; Mineau 2005; Schwarzbach et al. 2005; ElMekkawi et al. 2009). Mercury, which comes from both natural and anthropogenic sources, also possesses 
toxic qualities. Circulating in the lithosphere, atmosphere, hydrosphere and biosphere, mercury undergoes transformations. As a result of reduction, it changes into its volatile atomic form and, through methylation, to its most toxic organic form. In the atmosphere, mercury and pesticides can be transported over short and long distances by the wind or with migrating birds (Falandysz et al. 1999a; Blais et al. 2005).

The presence of xenobiotics in water ecosystems is dangerous, due to their durability and their bioaccumulative properties, and poses threats to the health and life of organisms on the highest trophic level. The presence of mercury and deposits of organochlorine pesticides have been determined in fish, mammal and aquatic bird species of the Baltics (Sapota 2006; Szefer et al. 1993; Polak-Juszczak 2009; HELCOM 2010).

Despite numerous studies, little is known about the circulation and transport of xenobiotics with water birds, even in terms of the largest flow at the highest trophic level. The aim of the research was an assessment of the influence of diet on the level of accumulation and detoxification in birds concerning mercury and chlorinated pesticides (aldrin, dieldrin, endrin, isodrin, $\alpha$ - and $\beta$ endosulfan isomers, endosulfan sulfate, methoxychlor (2,2-bis(p-methoxyphenyl)-1,1,1-trichloroethane), pp'dichlorodiphenyltrichloroethane (DDT) isomer and its metabolites pp'-dichlorodiphenyldichloroethylene (DDE) and pp'-dichlorodiphenyldichloroethane (DDD)). The study was focused on determining the dose of xenobiotics ingested with food and their accumulation in the muscle and fatty tissues, liver and brain of Spheniscus demersus. The African penguin, as it is commonly known, is a medium-sized bird of about 45-68 cm in height, weighing about $3 \mathrm{~kg}$. In the wild, it lives between 10 and 27 years and procreates only once a year (Whittington et al. 2000). In its natural environment, it can be found in the ecosystem of Bengal, where it feeds on pelagic fish as well as squid and shellfish (Crawford et al. 2006; Pearce 2010). Penguins in the Gdansk Zoo receive one type of food-herring (Clupea herengus) caught in the South Baltic region.

This unique type of experimental research can only be carried out in a zoo, where it is possible to fully control the food supply and behaviour of an entire bird colony. Additional studies were performed into guano, feathers and eggs, with which mercury and organochlorine pesticides are eliminated from the bird's system. This biological transportation passes pollutants directly to offspring in the earliest phases of life or else to the biotope of the coastal zone of the sea. The latter is secondary environmental contamination.

\section{Materials and Methods}

\subsection{Sampling}

Out of the total mass of herring periodically delivered to the zoo, three or four whole fish were selected at random in order to determine total mercury and organochlorine pesticide concentrations. This was repeated every month from December 2009 to February 2011. Among the selected 42 fish, there were both small specimens with a wet weight as little as $11.26 \mathrm{~g}$ and large ones weighing up to $247.01 \mathrm{~g}$. In the laboratory, the fish were weighed whole, subjected firstly to homogenisation and then to lyophylisation, after which the material was homogenised again. Mercury quantification was performed for all the fish, while organochlorine pesticide quantification was conducted for nine of them.

Guano was collected from the Spheniscus demersus run in the zoo, in which individual samples for mercury quantification were collected from a teflon mat onto fiberglass filters. Mercury quantification was carried out for 94 samples. One sample for the determination of persistent organic pollutants (POPs) contained guano from several specimens, accumulated on the teflon mat. Collective samples $(n=3)$ were put into teflon containers using teflon spoons.

Unhatched penguin eggs came from two breeding seasons: autumn 2009 and spring 2010. In the laboratory, the eggs were washed with distilled water, and where possible, the albumen and the yolk were separated. Two eggs contained embryos. The determination of organochlorine compounds was performed on three whole eggs and three sets of separated albumens and yolks. Total mercury quantification was carried out for 22 samples.

Penguin covert feathers were collected from live birds, always from the chest area. Three kinds of feathers were also collected from a dead female penguin: down feathers, covert feathers and scale-like feathers. In the laboratory, the feathers were cleaned in a $50 \%$ acetone bath, placed in an ultrasonic bath for 
$30 \mathrm{~min}$ and then rinsed three times in redistilled water. The feathers were dried for $24 \mathrm{~h}$ at room temperature. The muscle, liver, fatty tissue and brain tissue samples were obtained from dead birds through dissection. The cause of death was not investigated.

The biological material, fish, tissues and internal organs, was first homogenised and then lyophilised. In order to determine moisture, the material was weighed before and after lyophilisation. The average moisture content was found to be $69.99 \pm 2.57 \%$ in penguin muscles, $72.42 \pm 3.1 \%$ in the liver, $79.01 \pm 0.6 \%$ in the brain, $74 \pm 3.7 \%$ in whole eggs, $83.57 \pm 4.3 \%$ in egg albumens and $54.23 \pm 2.7 \%$ in the yolks.

\subsection{Reagents and Standards}

To determine POPs, standard organochlorine compound material was used. The material, supplied by AccuStandard, was over $99 \%$ pure (GC area $\geq 99.8 \%$ ). The extraction solvents, n-hexane, acetone and ntetradecane, also with a minimum purity of $99 \%$ ( $\mathrm{GC}$ area $\geq 99 \%$ ) for the chromatographic analysis, were supplied by Merck. In the procedure, the following were used: sulphuric acid (min. $95 \%$ ) and nitric acid (65\%), both ultra-analytically pure, from $\mathrm{POCH}$ and SPE columns with Thermo Scientific HyperSep type C18 cartridges, rounded cellulose extraction thimbles from Whatman. Also, technical gases from Linde were used: $99.995 \%$ pure oxygen and helium, and $99.994 \%$ pure nitrogen.

\subsection{Quality Control}

In laboratory work, the following were used: teflon containers for the tissue homogeniser, petri dishes for lyophilising eggs and spoons for guano sampling, all etched in $65 \% \mathrm{HNO}_{3}$. The nickel boats for the mercury analyser's feeder were heated at a temperature of $850{ }^{\circ} \mathrm{C}$ before an analysis sample was weighed out.

The accuracy of the total mercury quantification method was identified on the basis of an analysis of certified reference materials (BCR414 and BCR463), for which variable repeats were $5 \%$ and expanded uncertainty (RSD) was $1 \%$. The quantitation limit (MQL) obtained was $0.075 \mathrm{ng} \mathrm{g}^{-1} \mathrm{dw}$.

When analysing persistent organic pollutants, vessels and containers which came into contact with the samples were thoroughly washed and heated at $150{ }^{\circ} \mathrm{C}$ for $12 \mathrm{~h}$ (El-Mekkawi et al. 2009). The analytical method used made it possible to recover between 87.4 and $96.3 \%$ of the substance. The expanded uncertainties (RSD) were from $1.1 \%$ (for pp'-DDE) to $9.8 \%$ (for isodrin). The quantitation limit (MQL) for the studied compounds was between 1 and $4 \mathrm{pg} \mathrm{cm}^{-3}$.

\subsection{Sample Preparation and Extraction}

The following amounts were prepared for mercury analysis from the biological material: liver- $0.01 \mathrm{~g}$; fish and other penguin tissues, organs and eggs $-0.1 \mathrm{~g}$; feathers $-0.02 \mathrm{~g}$. Guano was quantified together with the filter.

POPs were extracted from lyophilised biological material with a minimum weight of $1 \mathrm{~g}$. Extracts were prepared under the Soxhlet method using a mixture of n-hexane and acetone at a ratio of $1: 1$. The extraction solvent was enriched with n-tetradecane as a keeper whose role was to keep the more volatile pesticides in the extract. The obtained extract was then concentrated and cleaned up with concentrated $\mathrm{H}_{2} \mathrm{SO}_{4}$ reaction in order to remove fats and further purified using the SPE method with C18 cartridges (Falandysz et al. 2001). The whole analytical procedure is shown in a diagram (Fig. 1).

\subsection{Determination}

Total mercury quantification was carried out using atomic absorption spectroscopy in an AMA-254 mercury analyser with a wavelength of $253.65 \mathrm{~nm}$. Oxygen was employed as the carrier gas, as well as an oxidant, and background verification consisted of subjecting a clean, empty boat to the same procedure. The quantification of each sample was repeated three times.

Organochlorine compound concentrations were determined using a gas chromatograph equipped with an electron capture detector ${ }^{63} \mathrm{Ni}$ (GC-ECD, Varian 450GC). Separation was carried out on a Varian capillary column of fused silica ( $50 \mathrm{~m}$ long, film thickness of $0.25 \mu \mathrm{m}$, external diameter of $0.53 \mathrm{~mm}$ and internal diameter of $0.70 \mathrm{~mm}$ ), with helium used as the carrier gas (flow speed of $5 \mathrm{~cm}^{3} \mathrm{~min}^{-1}$ ). The detector's temperature was set to $300{ }^{\circ} \mathrm{C}$ using a temperature programme presented by Vorkamp et al. (2004) but with a modified injection temperature of $250{ }^{\circ} \mathrm{C}$. The lipid content in the tissues was determined using the gravimetric method after Soxhlet method extraction. 
Fig. 1 Diagram on whole analytical procedure

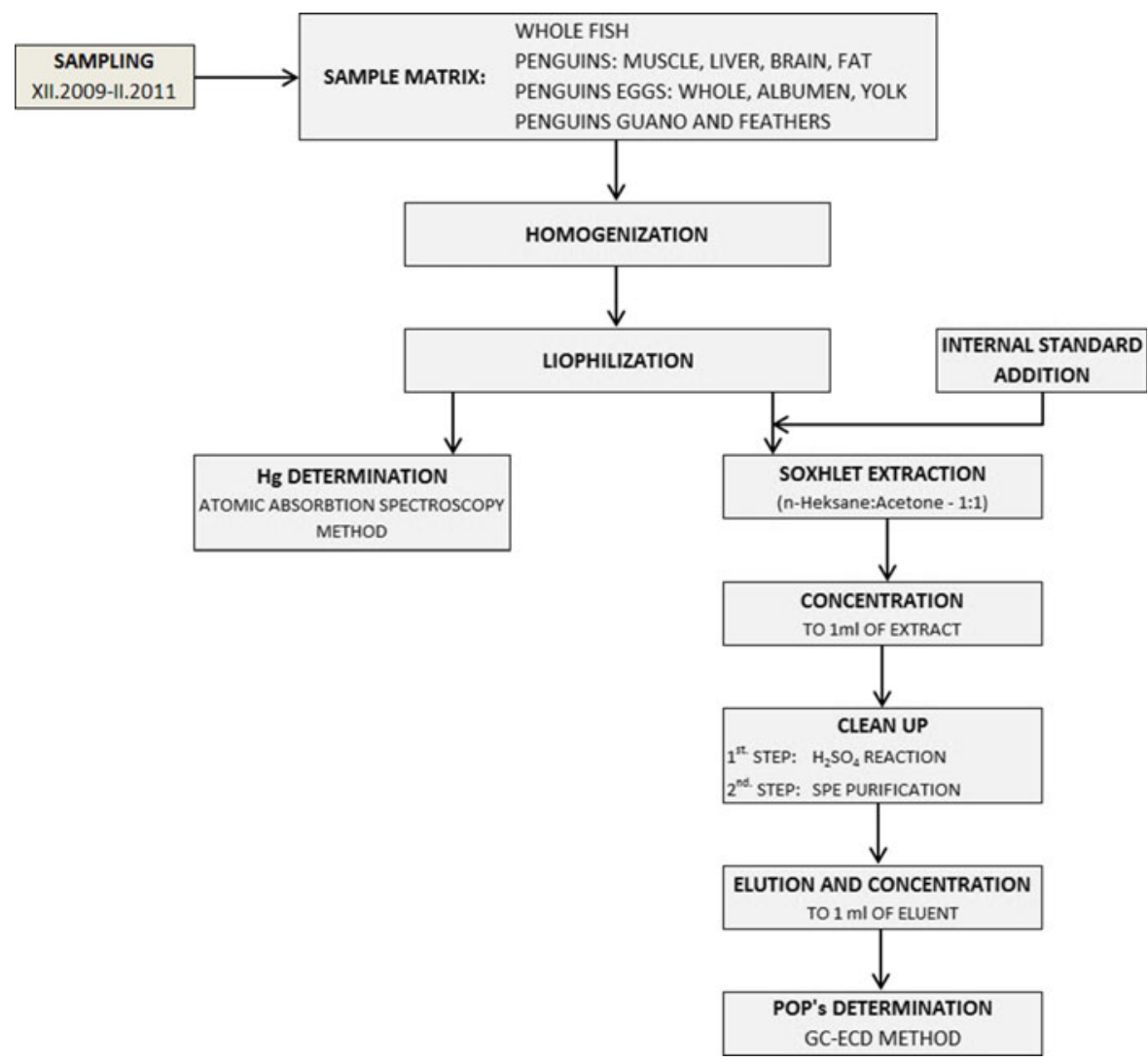

\section{Results}

3.1 Mercury and Pesticides in the Herring of the Southern Baltic

In whole herring (Clupea harengus) $(n=42)$, constituting the penguins' sole source of food, concentrations of total mercury occurred within the range of 7.35 to $69.28 \mathrm{ng} \mathrm{g}^{-1} \mathrm{sm}$. As mercury concentration in fish depends among other factors on the size (age) of the specimens, it was calculated that the smallest whole fish contained $36.47 \mathrm{ng}$ of total mercury, while the largest fish contained 4,837.02 ng. The nonparametric distribution of $\mathrm{Hg}$ concentrations in all the fish resulted in the use of a median (amounting to $31.81 \mathrm{ng} \mathrm{g}^{-1} \mathrm{sm}$ ) in further calculations.

The performed measurements of organochlorine pesticide concentrations in whole herring demonstrated the presence of $\alpha$-endosulfan (endosulfan 1), dieldrin, endrin and methoxychlor (Fig. 2a). The following were not detected: $\beta$-endosulfan isomer, endosulfan sulphate, aldrin and isodrin. The absence of the last two pesticides could result from the fact that they are metabolised into more permanent forms: dieldrin and endrin (Falandysz et al. 1999b). Additionally, the residue of DDT and its metabolites were found in the herring of the Southern Baltic catch-the penguins' food (Fig. 2b).

3.2 Mercury and Pesticides in the Liver, Muscle, Fatty and Brain Tissues of Penguins

In order to determine pesticides, three specimens were used: an 8-year-7-month-old female and two juvenile specimens of unknown sex, 6 and 7 months old. Mercury quantification was carried out on a 4month-old specimen of unknown sex and two nestlings: one 3 and the other 16 days old ( Fig. 3).

The concentrations of total mercury (Table 1) accumulated in the tissues and organs of penguins indicated that their system is loaded with it from the beginning of their lives, but no straightforward increase was observed with age. Among tissues and organs, the liver was characterised by the highest concentrations, whereas the fatty tissue had the lowest concentrations. A special case was the 3-day-old 


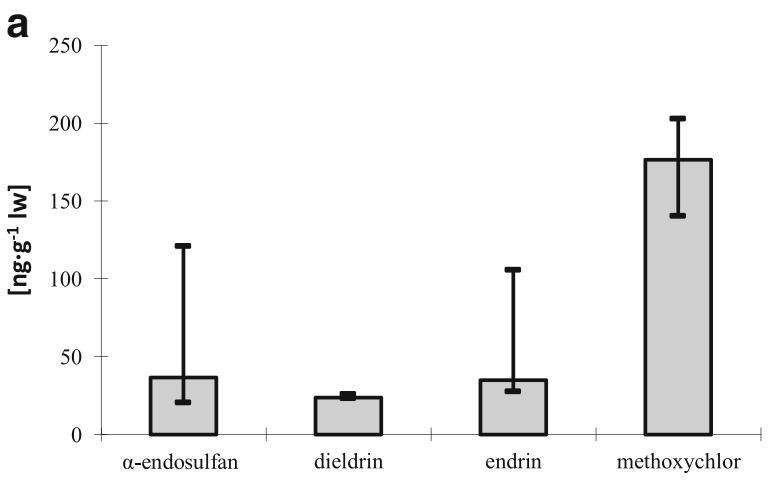

Fig. 2 The median and concentration range of a cyclodiene pesticides and methoxychlor and b DDT and its metabolites, converted to lipid weight in herring (Clupea harengus) caught in

nestling, all of whose internal organs had the highest $\mathrm{Hg}$ concentrations (the only exception being the liver of the 7-month-old penguin).

The study of the organochlorine compounds indicated the presence of $\alpha$-endosulfan at a level of $63.72 \mathrm{ng} \mathrm{g}^{-1} \mathrm{lw}$ in the muscles of the female. In the liver of the female, the pesticide's concentration was over $50 \%$ lower $\left(37.97 \mathrm{ng} \mathrm{g}^{-1} \mathrm{lw}\right)$ than in the muscles. The $\alpha$-endosulfan isomer was determined also in the fatty tissues of the female and the immature specimen (6 months old), amounting to respective concentrations of 101.21 and $86.70 \mathrm{ng} \mathrm{g}^{-1} \mathrm{lw}$. However, in the younger specimens, the compound was found in neither the muscles nor the liver. None of the brain samples were found to contain $\alpha$-endosulfan.

Dieldrin was not determined in the muscle tissue of the birds; it was found in the female's liver

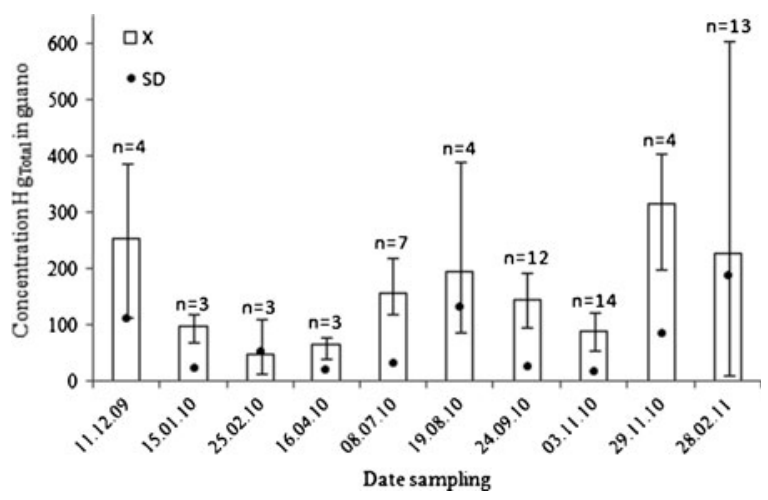

Fig. 3 Statistical characterisation of mercury concentration in the penguin guano $\left[\mathrm{ng} \mathrm{g}^{-1} \mathrm{sm}\right]$ collected at the run in the Gdansk Zoo between December 2010 and March 2011 ( $n$ number of sampling, $x$ mean value, $S D$ standard deviation, Min. minimal value, Max. maximal value) b

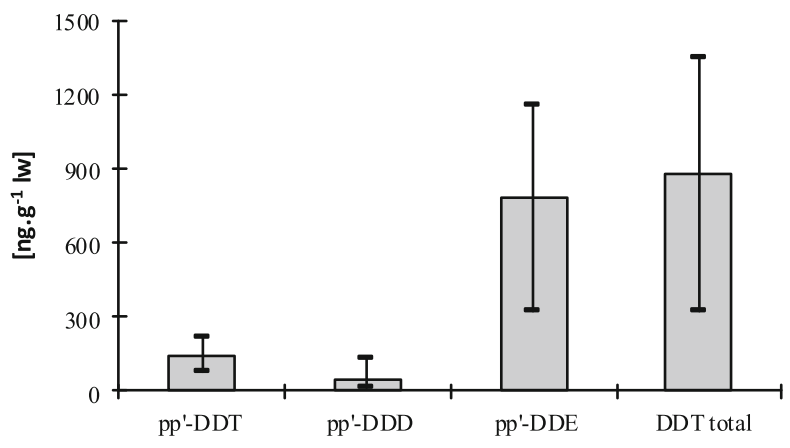

the southern Baltic as food for African penguins (Sphenescus demersus) living in the Gdansk Zoo (December 2009 to February 2011). The average lipid content in herring was $10.59 \pm 2.22 \%$

(166.50 $\left.\mathrm{ng} \mathrm{g}^{-1} \mathrm{lw}\right)$. This insecticide was also discovered in the fatty tissue of the adult female and the juvenile specimen ( 6 months old) at concentration levels of 53.27 and $17.44 \mathrm{ng} \mathrm{g}^{-1} \mathrm{lw}$, respectively. The same two birds were found to possess dieldrin in their brains, and these were the highest concentration values determined in the studied penguin tissues and organs (the 8-year-old female, $194.35 \mathrm{ng} \mathrm{g}^{-1} \mathrm{lw}$; the 6-monthold specimen, $80.31 \mathrm{ng} \mathrm{g}^{-1} \mathrm{lw}$ ).

Endrin was determined in the muscles, liver and fatty tissue of the female penguin at respective levels of 73.31, 118.20 and $260.19 \mathrm{ng} \mathrm{g}^{-1}$ lw. The 6-month-old juvenile specimen possessed endrin in its liver and fatty tissue at respective levels of 41.72 and $24.28 \mathrm{ng} \mathrm{g}^{-1} \mathrm{lw}$. Among the studied cyclodiene pesticides, endrin was the only one to be determined in the brain of each examined bird; in the 8-year-old female, it was at a level of $972.20 \mathrm{ng} \mathrm{g}^{-1} \mathrm{lw}$, while the 6- and 7-month-old specimens demonstrated 794.99 and $576.49 \mathrm{ng} \mathrm{g}^{-1} \mathrm{lw}$, respectively. $\beta$-Endosulfan isomer, endosulfan sulphate, isodrin, aldrin and methoxychlor were not found in any of the studied tissues and organs of penguins.

Total DDT was determined in all penguin tissues and organs (Table 2), but all isomers were found only in the 8-year-old female, where the highest $\mathrm{DDT}_{\text {Total }}$ concentration was discovered in the liver. Similar concentrations were determined in the brain.

\subsection{Mercury and Pesticides in Guano, Eggs and Feathers}

In the guano collected at random from a run inhabited by 70 penguins, the mean total mercury concentration amounted to $139.18 \mathrm{ng} \mathrm{g}^{-1} \mathrm{dw}(\mathrm{RSD}=24 \%)$, while the 
Table 1 Total mercury concentrations $\left[\mathrm{ng} \mathrm{g}^{-1} \mathrm{dw}\right.$ ] in the tissues and organs of African penguins (Spheniscus demersus) of various ages from the breeding colony in the zoo in Gdansk

\begin{tabular}{|c|c|c|c|c|c|c|}
\hline \multirow[t]{2}{*}{ Tissues/organs } & \multicolumn{6}{|l|}{ Age } \\
\hline & $3 \mathrm{D}^{\mathrm{AB}}$ & $16 \mathrm{D}^{\mathrm{AB}}$ & $4 \mathrm{M}^{\mathrm{AB}}$ & $6 \mathrm{M}^{\mathrm{AB}}$ & $7 \mathrm{M}^{\mathrm{SB}}$ & $8 \mathrm{Y} 7 \mathrm{M}^{\mathrm{PP}}$ \\
\hline Muscle & $1,529.38$ & 266.98 & 668.46 & $1,361.09$ & $1,162.91$ & $1,088.42$ \\
\hline Liver & $1,703.74$ & 630.35 & - & $1,627.77$ & $3,037.33$ & $1,461.47$ \\
\hline Brain & $1,033.44$ & 164.31 & 171.56 & 670.52 & 743.95 & 509.42 \\
\hline Fatty & - & - & 8.83 & 19.6 & 25.43 & 13.99 \\
\hline
\end{tabular}

$D$ day, $M$ month, $Y$ year, $A B$ autumn breeding, $S B$ spring breeding, $P P$ probable cause of death of the female-egg stoppage in the oviduct, December 2010

spread of $\mathrm{Hg}$ concentrations spanned from 4.6 to $604.4 \mathrm{ng} \mathrm{g}^{-1} \mathrm{dw}$. The randomly selected fresh samples were composed of the faeces of specimens of different ages, sexes and conditions (Fig. 2). There are no grounds to claim that the changes of $\mathrm{Hg}$ concentrations in penguin guano were seasonal. Similarly, no substantial statistical correlation was found between the mercury concentrations determined in the guano and the herring, randomly selected from the total amount intended as food for the penguins.

Additional research involving both live and dead birds made it possible to attribute total mercury concentrations in the guano to specimens of a certain age (Table 3). The obtained results showed that a 3-day-old nestling excreted guano with the highest total mercury concentration, compared to other specimens. Nonetheless, in the guano collected at the run from unidentified specimens, 6 out of 84 samples were found to contain similar mercury concentrations to that of the 3-day-old nestling.

In 22 eggs, coming from two breeding seasons, total mercury concentration was determined as a joint total of the values in the albumen and in the yolk. However, the two were separated when possible (Table 4).

$\mathrm{Hg}$ concentrations in eggs originating from the spring breeding season were over twice as high as those in eggs from the autumn. Mercury concentration increase in whole eggs occurred mostly due to its increase in the yolks. The $\mathrm{A} / \mathrm{Y}$ ratio in eggs in the spring breeding season was several times smaller than

Table 2 DDT and its metabolites' concentrations $\left[\mathrm{ng} \mathrm{g}^{-1} \mathrm{lw}\right]$ converted to lipid weight for tissues and organs of African penguins (Spheniscus demersus) living in the Gdansk Zoo

\begin{tabular}{|c|c|c|c|c|c|c|}
\hline & Age & Lipids [\%] & pp'-DDT & pp'-DDD & pp'-DDE & $\mathrm{DDT}_{\text {Total }}$ \\
\hline \multirow[t]{3}{*}{ Muscle } & $8 \mathrm{Y} 7 \mathrm{M}$ & 10.53 & 270.94 & BDL & $8,077.68$ & $8,348.62$ \\
\hline & $6 \mathrm{M}$ & 14.51 & BDL & 122.05 & $1,503.92$ & $1,629.97$ \\
\hline & $7 \mathrm{M}$ & 8.48 & BDL & 63.68 & $1,599.41$ & $1,663.05$ \\
\hline \multirow[t]{3}{*}{ Liver } & $8 \mathrm{Y} 7 \mathrm{M}$ & 8.69 & $1,653.85$ & 517.61 & $22,172.12$ & $24,343.58$ \\
\hline & $6 \mathrm{M}$ & 9.74 & BDL & 122.28 & $1,709.24$ & $1,831.52$ \\
\hline & $7 \mathrm{M}$ & 10.36 & 4.73 & BDL & $1,641.12$ & $1,645.85$ \\
\hline \multirow[t]{3}{*}{ Fatty } & $8 \mathrm{Y} 7 \mathrm{M}$ & 93.12 & 125.70 & BDL & $1,915.29$ & $2,040.99$ \\
\hline & $6 \mathrm{M}$ & 91.21 & 21.05 & BDL & $1,149.67$ & $1,170.72$ \\
\hline & $7 \mathrm{M}$ & 97.61 & BDL & BDL & 689.99 & 689.99 \\
\hline \multirow[t]{3}{*}{ Brain } & $8 \mathrm{Y} 7 \mathrm{M}$ & 22.27 & $3,625.55$ & 566.37 & $4,308.98$ & $8,500.90$ \\
\hline & $6 \mathrm{M}$ & 17.79 & $4,065.59$ & BDL & $1,590.33$ & $5,673.71$ \\
\hline & $7 \mathrm{M}$ & 19.48 & $\mathrm{BDL}$ & BDL & 637.94 & 637.94 \\
\hline
\end{tabular}

$B D L$ below detection limit 
Table 3 Mercury concentration in the guano collected during the dissection of dead birds or while taking blood samples from live birds in the Gdansk Zoo, during the period December 2009 to February 2011

\begin{tabular}{lr}
\hline $\mathrm{Hg}\left[\mathrm{ng} \mathrm{g}^{-1}\right] \mathrm{dw}$ & Age \\
\hline 478.4 & $3 \mathrm{D}$ \\
25.42 & $4 \mathrm{M}$ \\
50.68 & $6 \mathrm{M}$ \\
241.82 & $2 \mathrm{Y}$ \\
295.07 & $2 \mathrm{Y}$ \\
264.75 & $4 \mathrm{Y}$ \\
267.56 & $4 \mathrm{Y}$ \\
104.49 & $4 \mathrm{Y}$ \\
141.72 & $11 \mathrm{Y} 4 \mathrm{M}$ \\
159.82 & $11 \mathrm{Y} 4 \mathrm{M}$ \\
\hline
\end{tabular}

$D$ day, $M$ mouth, $Y$ year

in the autumn. Where separation was possible, $\mathrm{Hg}$ concentrations in the albumen were nearly ten times higher than those of the yolk in the normally coloured eggs from the autumn breeding season (eggs no. 7, 8 and 9), while in the spring, the $\mathrm{A} / \mathrm{Y}$ ratio was smaller. Additionally, an increase in the yolk weight was to be observed, and in an extreme case (egg no. 10 from the spring breeding season), the yolk weight exceeded the albumen weight.
Total mercury concentrations in various penguin feathers were characterised by relatively high variability, ranging from 157.84 to $4899.47 \mathrm{ng} \mathrm{g}^{-1}$. The distribution of $\mathrm{Hg}$ concentrations was non-parametric. On the basis of all 77 results, the mean concentration value was determined to be at a level of 2,019.30 $\mathrm{ng} \mathrm{g}^{-1}(\mathrm{RSD}=279 \%)$, while the median amounted to $1,850.65 \mathrm{ng} \mathrm{g}^{-1}$.

The results showed that mercury concentration in penguin covert feathers depended on the age of the birds (Fig. 4). In juvenile specimens under 1 year old, mercury concentration in feathers ranged slightly but was two times lower when compared with adults, amounting to $775 \mathrm{ngHg} \mathrm{g}^{-1}(\mathrm{RSD}=130 \%)$. Among the adult specimens, two sets could be distinguished: the first had a small range of concentrations with a mean value of 1,932 $\operatorname{ngHg~g}^{-1}(\mathrm{RSD}=176 \%)$, and the other (marked with the oval) had over twice as high $\mathrm{Hg}$ concentrations, suggesting probable physiological/pathological changes in the 8-year-old female. In the three types of feathers taken from the female, total mercury concentrations were determined in the down $\left(4,624 \mathrm{ngHg} \mathrm{g}^{-1}(\mathrm{RSD}=291 \%)\right)$, covert feathers $\left(3,985 \mathrm{ngHg} \mathrm{g}^{-1}(\mathrm{RSD}=357 \%)\right)$ and scale-like feathers $\left(3,725 \mathrm{ngHg} \mathrm{g}^{-1}(\mathrm{RSD}=265 \%)\right)$, and the changes between them were statistically significant $(p<0.05)$. This probably resulted from the fact that different feathers were formed at different times and took longer or shorter to grow.

Table 4 The characterisation of mercury concentrations in ungerminated and unhatched penguin eggs $\left[\mu \mathrm{g} \mathrm{g}^{-1} \mathrm{dw}\right]$ from the autumn 2009 and spring 2010 breeding seasons in the Gdansk Zoo (excluding shells and membranes)

\begin{tabular}{|c|c|c|c|c|c|c|c|c|c|}
\hline \multicolumn{5}{|c|}{ Autumn 2009} & \multicolumn{5}{|c|}{ Spring 2010} \\
\hline No & $\begin{array}{l}\text { Weight egg [g ww] } \\
\text { albumen/yolk }\end{array}$ & $\begin{array}{l}{[\mathrm{Hg}]} \\
\text { albumen/ } \\
\text { yolk }\end{array}$ & $\begin{array}{l}\mathrm{A} / \mathrm{Y} \\
\text { ratio }\end{array}$ & $\begin{array}{c}\Sigma[\mathrm{Hg}] \\
\text { albumen+yolk }\end{array}$ & No & $\begin{array}{l}\text { Weight [g ww] } \\
\text { albumen/yolk }\end{array}$ & $\begin{array}{l}{[\mathrm{Hg}]} \\
\text { albumen/ } \\
\text { yolk }\end{array}$ & $\begin{array}{l}\mathrm{A} / \mathrm{Y} \\
\text { ratio }\end{array}$ & $\begin{array}{c}\Sigma[\mathrm{Hg}] \\
\text { albumen }+ \text { Yolk }\end{array}$ \\
\hline 1 & 67.14 & - & - & 1.03 & 1 & 75.66 & - & - & 0.93 \\
\hline 2 & 21.62 & - & - & 0.44 & 2 & 65.66 & - & - & 1.08 \\
\hline 3 & 59.89 & - & - & 0.75 & 3 & 50.50 & - & - & 0.96 \\
\hline 4 & 59.09 & - & - & 0.59 & 4 & 68.32 & - & - & 1.42 \\
\hline 5 & 47.50 & - & - & 0.33 & 5 & 56.76 & - & - & 1.51 \\
\hline 6 & 78.76 & - & - & 1.33 & 6 & 83.43 & - & - & 1.35 \\
\hline 7 & $62.35 / 27.20$ & $0.65 / 0.06$ & 10.03 & 0.72 & 7 & 77.84 & - & - & 1.16 \\
\hline 8 & $36.59 / 20.82$ & $0.56 / 0.06$ & 10.01 & 0.62 & 8 & $41.39 / 32.71$ & $0.71 / 0.29$ & 2,43 & 1.00 \\
\hline 9 & $50.98 / 27.50$ & $0.82 / 0.09$ & 9.01 & 0.91 & 9 & $43.91 / 20.88$ & $0.68 / 0.13$ & 5.44 & 0.81 \\
\hline \multirow[t]{3}{*}{10} & $99.65 / 31.36^{\mathrm{a}}$ & $6.46 / 0.33$ & 19.46 & 6.79 & 10 & $34.02 / 36.8$ & $0.76 / 0.41$ & 1.63 & 1.17 \\
\hline & & & & & 11 & $7.17^{\mathrm{b}}$ & & & 0.93 \\
\hline & & & & & 12 & $80.00^{\mathrm{b}}$ & & & 1.20 \\
\hline
\end{tabular}

$\mathrm{A} / \mathrm{Y}$ concentration ratio of $\mathrm{Hg}$ in albumen to yolk. ${ }^{\mathrm{a}}$ Unusual colour of the egg suggesting pathology of the egg (result excluded from the discussion). ${ }^{\mathrm{b}}$ Embryo 


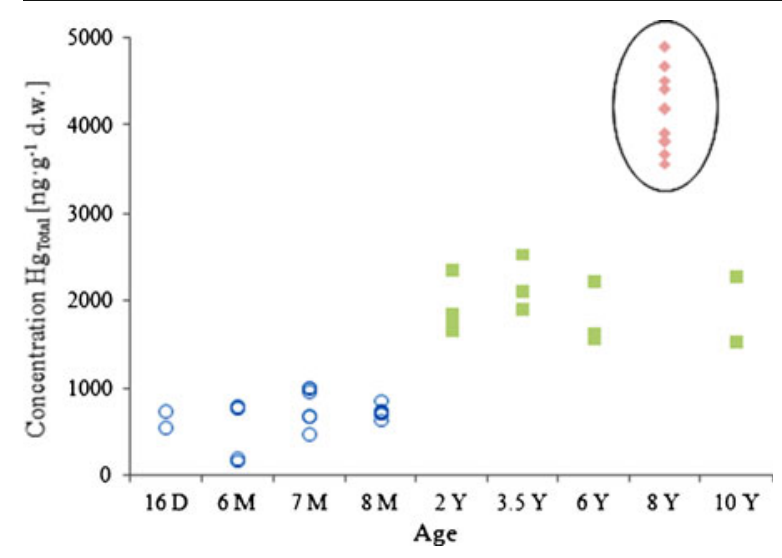

Fig. 4 The relationship between total mercury concentrations in feathers and the age of the penguins from Gdansk Zoo (2009-2011)

The pesticides which were not present in the penguins' food (aldrin, isodrin, $\beta$-endosulfan isomer and endosulfan sulphate) were also found to be absent in the penguins' internal tissues, eggs, feathers and guano (Table 5). However, all the pesticides present in the food were discovered in the yolk.

\section{Discussion}

\subsection{Penguins' Diet}

The sole food of the penguins living in the Gdansk Zoo is herring caught in the Southern Baltic. The relevant literature from the end of the previous century, as well as more recently, suggests that there is a constant downward trend in terms of xenobiotic concentration in fish (HELCOM 2010).

Earlier studies of herring (Clupea harengus) from the Gulf of Gdansk proved the occurrence of dieldrin at a level of $70 \mathrm{ng} \mathrm{g}^{-1} \mathrm{lw}$ (Falandysz et al. 1999b). After over 10 years, the results of pesticide concentration in herring from the same region showed that the median of dieldrin concentration was about three times smaller (Fig. 1). Moreover, the present studies have shown a relationship between $\mathrm{DDT}_{\text {Total }}$ in fish and the size (age) of the specimens. In the smallest fish, $\mathrm{DDT}_{\text {Total }}$ concentration amounted to $325.12 \mathrm{ng} \mathrm{g}^{-1} \mathrm{lw}$, and in the largest 1,352.22 ng $\mathrm{g}^{-1} \mathrm{lw}$ (Fig. 1). Earlier studies by Pikkarainen (2008) also indicated an increase in DDT concentration with age.

A similar tendency was demonstrated by the results of studies carried out in the previous decade on mercury concentration in herring caught in the Southern Baltic. They proved a decrease in $\mathrm{Hg}$ concentration in tissues and organs (Usydus et al. 2004; HELCOM 2010). Among commercially caught fish, the Baltic herring was characterised by the lowest $\mathrm{Hg}$ concentrations in tissues and internal organs (Kwaśniak et al. 2012).

The average daily intake of food per penguin is about $0.5 \mathrm{~kg}$ of whole herring. Taking into account the mean xenobiotic concentration determined in the fish (3.1), it was possible to estimate a diurnal dose of pesticides and mercury introduced to the system through the food (Table 6). The highest doses of

Table 5 Organochlorine hydrocarbons in African penguin (Spheniscus demersus) guano, feathers [ng g $\left.{ }^{-1} \mathrm{dw}\right]$ and eggs [ng g $\left.{ }^{-1} \mathrm{lw}\right]$. The bases of feather and guano analyses were collective samples

\begin{tabular}{|c|c|c|c|c|c|}
\hline \multirow[t]{2}{*}{ Compounds } & \multirow[t]{2}{*}{ Feathers $(n=1)$} & \multirow[t]{2}{*}{ Guano $(n=3)$} & \multicolumn{3}{|l|}{ Eggs } \\
\hline & & & Albumen $(n=3)$ & Yolk $(n=3)$ & Whole egg ${ }^{\mathrm{a}}(n=3)$ \\
\hline Lipids (\%) & - & - & 0.54 & 56.20 & 43.21 \\
\hline$\alpha$-Endosulfan & 16.22 & 1.51 & 0.44 & 8.47 & 15.97 \\
\hline Dieldrin & 49.17 & 21.93 & BDL & 20.71 & 23.56 \\
\hline Endrin & BDL & 0.74 & 0.41 & 8.50 & 10.50 \\
\hline Methoxychlor & 91.25 & BDL & 0.28 & 3.46 & 42.45 \\
\hline pp'-DDT & 27.26 & 16.42 & 0.37 & 3.10 & 8.33 \\
\hline DDD & BDL & 3.26 & 0.34 & 0.67 & 2.78 \\
\hline DDE & 93.95 & 121.89 & 183.60 & $6,291.59$ & $9,416.67$ \\
\hline $\mathrm{DDT}_{\text {Total }}$ & 121.21 & 141.49 & 183.86 & $6,295.14$ & $9,429.93$ \\
\hline
\end{tabular}

$B D L$ below detection limit, $n$ number of samples. ${ }^{\text {a }}$ Excluding shell and membrane 
Table 6 Estimation of organochlorine compounds and mercury dose on day $\left[\mu \mathrm{g} \mathrm{day}{ }^{-1}\right]$ supplied to penguins with $0.5 \mathrm{~kg}$ food

\begin{tabular}{ll}
\hline Compounds & Mean dose \\
\hline$\alpha$-Endosulfan & 1.8 \\
Dieldrin & 0.8 \\
Endrin & 1.4 \\
Methoxychlor & 5.3 \\
pp'-DDT & 4.3 \\
pp'-DDD & 1.8 \\
pp'-DDE & 23.4 \\
DDT $_{\text {Total }}$ & 27.5 \\
$\mathrm{Hg}_{\text {Total }}$ & 4.6 \\
\hline
\end{tabular}

pesticides introduced with the food were those of DDT. With mercury, the daily dose ranged from 1 to $10 \mu \mathrm{g}$. Within this dose, the most toxic form, methylmercury, which is the easiest to absorb while digesting food, had the highest proportion (Wiener et al. 2003; Kwaśniak et al. 2012). It is worth pointing out here that even during the first day of their lives, penguin nestlings are fed with herring which has been predigested by their parents.

It follows from the estimation that every year, up to $10 \mathrm{mg}$ of total DDT and just under $2 \mathrm{mg}$ of $\mathrm{Hg}$ can be supplied to the system of the consumer. However, the range of xenobiotic concentration results may be quite extensive as the meal of a penguin, depending on the size of the fish, may consist of several relatively large fish or over 40 smaller ones. Moreover, specimens up to 2 months old receive less food than all other penguins. The differences in the volume of consumption can also be determined by gender, breeding time or molting (Burger and Gochfeld 1997; Braune 2007).

\subsection{Mercury and Pesticide Accumulation}

Organic mercury - methylmercury - penetrates into a penguin's organs through the digestive system. It is absorbed by the intestinal walls and transported with blood to all tissues and deposited in various cells (Wiener et al. 2003; Braune 2007).

The studies on the accumulation of mercury and organochlorine pesticides were primarily concerned with muscle tissue, fatty tissue and the brain, although the scope of the study was later expanded to include the liver, which has the capacity to store, redistribute, detoxicate and transform. The concentrations of both mercury and most of the analysed pesticides were higher in penguins' livers than in their muscles, which demonstrated the level of storage and indicated prolonged exposure to xenobiotics. In piscivorous birds, the level of $\mathrm{Hg}$ concentration in the liver can reflect the result of the degradation of recent meals containing protein, where $\mathrm{MeHg}$ bonds with. The liver can thus be a useful indicator of alimentary exposure (Bond and Diamond 2009a, b).

There are two main factors which determine xenobiotic concentration in birds: diet and age. The penguins from the Gdansk Zoo, compared with other aquatic birds, have a very uniform diet consisting solely of the Baltic herring. This is why the mercury load on their systems has to be considered moderately high (Table 1) when compared with adult specimens of Larus argentatus and Larus marinus from the South Baltic region and Larus argentatus from Siberia, whose diets contain large proportions of sea fish (Kim et al. 1996; Szumiło et al. 2013). The $\mathrm{Hg}_{\text {Total }}$ concentration results obtained by Schwarzbach et al. (2005) in the muscles and liver of gulls feeding solely on sea fish in the San Francisco Bay were by an order of magnitude higher than in penguins, suggesting a sublethal effect of mercury on adult birds.

Previous studies of birds of prey over the Baltics (in the 1990s) showed that concentrations of $\mathrm{DDT}_{\text {Total }}$ in the chest muscles of the white-tailed eagle (Haliaeetus albicilla) ranged from 3.1 to $4,700 \mathrm{ng} \mathrm{g}^{-1} \mathrm{lw}$. Endrin was not determined at that time (Falandysz et al. 2000). In 2000, the presence of DDE at a level of $12,900 \mathrm{ng} \mathrm{g}^{-1}$ lw was found in the muscles of the Baltic guillemot (Uria aalge) (Lundstedt-Enkel et al. 2006). However, studies into fish-eating birds in the Southern Baltic region in recent years have proved a decrease in total DDT concentration in their tissues and organs. This was confirmed by studies of the muscles of Larus fuscus nestlings in the Gulf of Finland and the Gulf of Bothnia. DDT ${ }_{\text {Total }}$ concentrations in 1980 were determined to be as high as $833 \mathrm{ng} \mathrm{g}^{-1} \mathrm{lw}$, while in 2000, the maximal concentrations ranged between 117.6 and $212.8 \mathrm{ng} \mathrm{g}^{-1} \mathrm{lw}$, depending on the region (Hario and Nuutinen 2010). The present studies confirm the drop in DDT and its metabolites' concentration in herring (i.e. the penguins' food), but do not prove that xenobiotic concentrations are decreasing in the penguins' own systems. Constant administration of food containing even small doses of toxic substances results in their 
biomagnification and has adverse effects on prolonged exposure. It is worth stressing that the accumulation of organochlorine compounds depends on the fat content in tissues, while the accumulation of mercury depends on an increase in the binding sites in the protein fraction, as was discovered in fish (Nakao et al. 2007). Herring, belonging to the group of pelagic planktivorous fish, have the lowest total mercury concentrations among the fish commercially caught in the Southern Baltic. This results from a high concentration of lipids in these fish and may serve as an explanation as to why the accumulation of lipophilic pesticides in the fish constituting penguin food (Table 1) is more effective than mercury accumulation (Table 2).

Information found in literature indicates that the level of mercury and organochlorine pesticides in the tissue and organs of aquatic birds can be related to their age (Donaldson et al. 1997). In two penguins under 1 year old, the concentrations of DDT and its metabolites in the liver, muscles, fat and brain were clearly lower than in the samples collected from the 8-year-old female. The 6month-old specimen was an exception, as its brain contained a higher pp'-DDT concentration than the brains of the other penguins. At each stage of life, the concentrations of endrin, diendrin and pp'-DDT isomer were found to be higher in the liver than in the muscles. These results confirm that the accumulation of xenobiotics in the liver increases with age, when detoxification is slow during chronic alimentary exposure, as suggested by Donaldson et al. (1997).

Methylmercury, released in the alimentary canal during digestion, penetrates the intestinal membranes by means of active transportation and, forming a complex with L-cystein, crosses the blood-brain barrier. The brain is the destination organ for mercury and organochlorine pesticide accumulation, especially DDT and its metabolites (Tables 1 and 2). The 3day-old nestling's brain had a total mercury concentration six times higher than the 16-day-old nestling and twice as high as the 8-year-old female. Similar observations were made in the Gulf of Gdansk in 2010. An unhatched Larus argentatus nestling from the spring breeding season had in its brain, seven times higher mercury concentration than in the older nestlings (a dozen or so days old) that had fallen out of their nest (unpublished results). The drastic drop observed in mercury concentration in each internal organ in the 16-day-old nestling, when compared with the 3day-old one, may result from a rapid removal of mercury from the system with guano (Table 3) and in the formation of feathers (Fig. 4). The death of the 3-day-old nestling, however, may signify that the level of physiological detoxification from mercury had been exceeded.

\subsection{Detoxification}

Birds are well known to be biomonitors of environmental pollution, and their eggs, feathers and guano constitute valuable research material, collected from the environment in a non-invasive way. Published over 40 years ago, the study results of Porter and Wiemeyer (1969) proved the negative effect of dieldrin and DDT and its metabolites on bird reproductive success by diminishing the thickness of eggshells and the weight of eggs. The threats related to high xenobiotic concentrations in birds' food include disorders in embryo development, embryo mortality and increased number of ungerminated eggs, as well as behavioural anomalies and infertility in adult specimens (Burger and Gochfeld 1997; Mineau 2005; Schwarzbach et al. 2005; Braune 2007).

\subsubsection{Guano-Xenobiotic Elimination over a Short Period of Time}

The considerable range in the total mercury concentrations which characterised penguin food was found also in the guano. Excretion is a form of detoxification which applies mostly to non-organic mercury. Environmental studies have confirmed a wide range of mercury concentrations in the guano of several different species of penguin, with the results reaching up to $400 \mathrm{ng} \mathrm{g}^{-1} \mathrm{dw}$. (Yin et al. 2008). However, in the gull guano collected on the beaches of the Gulf of Gdansk (Southern Baltic), the range of mercury concentrations was determined to be between 0.07 and 2,100 $\mathrm{ng} \mathrm{g}^{-1}$, with the highest concentrations occurring along the Hel Peninsula, which hosts colonies of birds feeding on fish and the insides of fish gutted directly on fishing boats returning to several small fishing harbours after the catch (Falkowska et al. 2008). Despite the fact that a relationship between the xenobiotic concentration in the diet and in the guano would seem obvious, no statistically significant relationship was found between mercury concentrations in the randomly selected fish (i.e. the food) and in the guano of the penguins from the zoo. 
The guano obtained during the dissection of the 3day-old nestling confirmed the mercury infection discovered in its system (Sect. 3.2). At the beginning of its life, the hatched nestling was excreting mercury received during its embryonic growth and from the food provided by its parents from as early as the first day after hatching. The nestling's guano was found to contain one of the highest mercury concentrations that were determined in the material collected from the run and the highest in the material collected directly from any specimen, alive or dead (Table 6). It's death was therefore the result of development disorders caused by high mercury concentrations and conceivably other xenobiotics.

\subsubsection{Eggs-Xenobiotic Elimination Twice a Year}

On the basis of the examinations of penguin eggs from the zoo, the presence of dieldrin, endrin and $\alpha$ endosulfan isomer was confirmed. The presence of relatively durable dieldrin and endrin compounds and the absence of aldrin and isodrin could have resulted from metabolic changes which had occurred in the female (Table 5). Dieldrin concentration values in penguin eggs were over 70 times higher than its concentrations detected 15 years before in the eggs of the white-tailed eagle (Haliaeetus albicilla) (Falandysz et al. 2000), although the eagle's diet changes throughout the year; in winter, it often feeds on animal carcasses, while at other times, aquatic birds and fish form the main food sources. The penguin, however, follows the same diet all year round - the Baltic herring. Thus, the differences in the pesticide concentrations in eggs could have resulted from the differences between the diets of wild birds and birds kept in the zoo. The more diverse diet of the white-tailed eagle inhabiting the northwest coast of the Baltics, as compared to that of penguins from the zoo (Table 5), could therefore have affected the DDT ${ }_{\text {Total }}$ concentrations $\left(270 \mathrm{ng} \mathrm{g}^{-1} \mathrm{lw}\right)$ in the eggs (Falandysz et al. 2000). DDT and its metabolites occurred in whole eggs, as well as in the albumens and yolks of the penguins' eggs. Higher concentrations of DDT and its metabolites were found in the yolk due to its affinity with lipids. In the eggs of the wild specimens of the guillemot (Uria aalge), which feed on sea fish, the concentrations of DDT and its metabolites were found to be an order of magnitude higher (Lundstedt-Enkel et al. 2006) than in the zoo penguins. Concentration results obtained
10 years ago by Lundstedt-Enkel in comparison with those of the present study may suggest a downward trend in pesticide content, both in the fish of the Baltics and the guillemot (Uria aalge).

The deposition of mercury into the forming egg influences changes in mercury and pesticide content in the systems of female birds. A female penguin in the zoo usually lays eggs twice a year, one or two eggs at a time, though in special cases it can be as many as three. On the basis of the results, it can be said that while laying eggs, she removes from her system between 5.1 and $17.8 \mu \mathrm{g} \mathrm{Hg}$ into one egg and that this may result in the removal of no more than $5 \%$ of the mercury absorbed with food if four eggs are laid per year. The transfer of organochlorine pesticides into four eggs a year may eliminate a portion of toxins in the range of $4.9-19.3 \%$. This does not constitute a high share in the detoxification process, but the aspect related to removing toxins (mercury, cyclodiene pesticides and insecticides) into the egg appears to have a considerable effect on the breeding success of the penguins. The load of mercury, for example, which is introduced into the egg is extremely toxic for the embryo, and its volume can determine whether or not the egg hatches. According to Burger and Gochfeld (1997), failure to hatch can occur at a concentration level of $1.5 \mu \mathrm{gHg} \mathrm{g}^{-1} \mathrm{dw}$ in the egg. Schwarzbach et al. (2005) determined the mercury concentration value of $1.0 \mu \mathrm{g} \mathrm{g}^{-1} \mathrm{ww}$ in the egg as the limit value for hatching. Braune (2007), based on literature analysis, quoted the $\mathrm{Hg}$ concentration between 0.5 and $2 \mu \mathrm{g} \mathrm{g}^{-1}$ ww as being sufficient to cause disorders in reproductive success. In the penguins' eggs (Table 4), there was only one case where $\mathrm{Hg}$ concentration was higher than $1 \mu \mathrm{g} \mathrm{g}^{-1} \mathrm{ww}$, while in four eggs, the concentrations were within the limits of $0.5-1.0 \mu \mathrm{g} \mathrm{g}^{-1} \mathrm{ww}$. It can be concluded therefore that ungerminated eggs and failures to hatch may be consequent upon increased mercury concentrations. As follows from a report by Schwarzbach et al. (2005), due to a high concentration of the metal passed from the female (especially during the first phase of embryo development), the hatched nestling is susceptible to the lethal effect of mercury. It ought to be stressed that the same eggs were found to contain other xenobiotics: $\mathrm{HCBz}, \mathrm{PCB} z, \mathrm{TCBz}$ and $\gamma$ HCH (Reindl et al. 2013).

According to the information provided by the penguin keepers, the penguins' breeding success has remained at a level of $15 \%$ since 2007 and has been 
higher than before since vitamins have been included in the birds' diet (A, D3, E, C, B1, B12, D-pantothenate, ferrous fumarate, inositol, folic acid, choline bitartrate, kelp and biotin). Nonetheless, the average lifespan of the penguins from the zoo is a half shorter than those living in the wild.

On the basis of mercury concentrations found in the eggs of seven different marine bird species, Bond and Diamond (2009a) determined concentration values which were ten times higher in the albumen than in the yolk. As mercury binds with the sulphhydryl groups of proteins, owing to its affinity with sulphur, most mercury can be found in the albumen. The proportions $\mathrm{A} / \mathrm{Y} \approx 10$ were determined in normally coloured eggs from the autumn breeding season where the yolk and the albumen could be separated (eggs no. 7, 8 and 9), while deviations occurred in the spring breeding season, and the A/Y ratio was found to be severalfold smaller. The fact that mercury concentrations in the spring eggs were twice as high as in the autumn eggs could not have resulted from the penguins' diet, and therefore, other possible causes ought to be pointed out.

A female which in spring lays eggs that fail to hatch reattempts after half a year, in autumn. This is the second time she has cleansed her system of xenobiotics, and autumn eggs are characterised by lower mercury concentrations. However, the relationship does not result directly from the second detoxification and mercury deposition into the laid eggs, but more from the fact that penguins enter the molting season between the two breeding seasons.

\subsubsection{Feathers-Xenobiotic Elimination Once a Year}

The detoxification of birds from xenobiotics via feathers takes place through molting, when birds simultaneously shed old feathers and grow new ones.

It is stated in literature that age has no relation to mercury concentrations in the feathers of fully grown birds and that $\mathrm{Hg}$ is higher in adult specimens than in nestlings. Similar conclusions seem to result from the study of penguin feathers (Fig. 4). This results from the fact that in fully grown birds, $\mathrm{MeHg}$ accumulated in tissues and organs in the periods between moltings is carried by the blood into the feathers. The mercury in the feathers of nestlings, however, comes from the egg and soft tissues accumulating mercury in a shorter time, equivalent to the length of their lives so far, which is under 1 year.

The highest concentrations of mercury, determined in the feathers of the 8-year-old female, are a special case (Fig. 4). A probable explanation of the result is the fact that certain birds can control mercury accumulation in their organism, not only by excretion through molting but also by demethylation metabolism (Kim et al. 1996). This hypothesis may be extended to penguins, showing that the ability to demethylate organic mercury in their liver depends on the age and condition. Juvenile specimens with high demethylation can protect themselves from methylmercury better than adult ones; they have a better ability to transform $\mathrm{MeHg}$ into the inorganic form, which is why its proportion in the total mercury concentration $\left(\mathrm{Hg}_{\mathrm{Total}}=\mathrm{MeHg}+\mathrm{Hg}^{2+}\right)$ in their livers is higher than in adults. They also appear to have a slower molting potential. Poor demethylation ability in adult specimens results in excretion of methylmercury in the alternative way, through molting. This would explain the special case of the 8-year-old female that died during the second breeding season in 2009 (December). In her feathers, the $\mathrm{Hg}$ concentration was almost five times higher than in other living adult specimens. The adverse effect of mercury load in the liver should be linked with a reduction in metallothionein and glutathione concentrations. These proteins bind inorganic mercury after demethylation and expel it from the liver, but glutathione as an antioxidant is needed for free radical neutralisation and organochlorine pesticide detoxification. Reduced glutathione is synthesised in cells in the presence of vitamin C, but its levels in the liver are gradually reduced with age (Rooney 2007). A low blood glutathione level indicates problems that the system is having with the removal of free radicals, which damage cells in the brain and other organs. When the glutathione level is not appropriate, cell apoptosis takes place. It seems that the range of mercury concentrations in feathers, considered by Burger and Gochfeld (1997) to have adverse effects including impaired reproduction $\left(5-40 \mu \mathrm{g} \mathrm{g}^{-1}\right)$, may have been confirmed by environmental studies. The 8 -year-old female from the zoo probably died as a result of egg stoppage in the oviduct, with mercury concentration approaching the critical value in the down $\left(4.6 \pm 0.2 \mu \mathrm{g} \mathrm{g}^{-1}\right)$ and in covert feathers $\left(4.0 \pm 0.3 \mu \mathrm{g} \mathrm{g}^{-1}\right)$.

Thus, within one species on the same trophic level, feathers can be an indicator of demethylation effectiveness and of general condition. Further studies are needed, however, to test the proposed hypothesis. 
Bond and Diamond (2009b) pointed out the necessity of such studies in their paper.

4.4 Xenobiotic Bioaccumulation in the Tissues and Organs of Penguins

The degree of vulnerability to xenobiotics varies among different bird species, but researchers agree that mercury and pesticides can result in premature death, reduce hatching and diminish the chances of survival at each stage of development (Burger and Gochfeld 1997; Spalding et al. 2000; Wiener et al. 2003; Mineau 2005; Schwarzbach et al. 2005). The material collected in the zoo enabled an estimation of the factors of mercury and pesticide accumulation in tissues and internal organs in relation to xenobiotic concentration in the food (Table 7).

The bioaccumulation factors (BAF) $\geq 1$ testify to the accumulation of xenobiotics in the muscles, liver and brain of the penguins. It appears that in penguins, the level of POP accumulation can grow with age, while for mercury, it can decrease. However, this proposition needs to be verified by further studies. It follows from calculations that most organochlorine pesticides were accumulated in the penguin's brain, and an explanation for this may be the chemical affinity of the studied organochlorine compounds with lipids (Table 2). An exception was pp'-DDE which, like mercury, reached the highest BAF values in the liver. This would suggest the role of the liver in xenobiotic transformation and the subsequent distribution of xenobiotics to the muscles, brain and other organs. In the liver, methylmercury undergoes demethylation to its non-toxic form, and DDT isomer becomes depolymerised to $\mathrm{pp}$ '-DDE.

\section{Summary}

The residues of POPs and mercury are still present in many components of the environment. Their durability and ability to accumulate in the food web influence the condition of living organisms. Penguins, occupying the highest trophic level, are an indicator of the level of environmental pollution in the area they live in and from which they obtain their food. In the zoo, $36.75 \mu \mathrm{g}$ of organochlorine pesticides and $4.6 \mu \mathrm{g}$ of mercury (mostly in the organic form) are introduced into their systems daily. The penguins' livers can be considered the best indicators of alimentary exposure.

The brain is the destination organ for mercury accumulation and has the highest accumulation factors for dieldrin, endrin and DDT and its metabolites.

On the basis of the obtained results, it can be stated that the detoxification of a penguin's system from xenobiotics takes place through feathers, eggs and deposition in guano. During the present studies, these methods of removal concerned mercury and all of the organochlorine pesticides determined in the food, and the results of these studies showed that xenobiotics introduced with food are characterised by various levels bioaccessibility and different speeds and modes of removal from the system. Xenobiotic elimination with guano takes place several times a day and covers only a small fraction of their content in food. However, it is the quickest route of xenobiotic removal from the system and, at the same

Table 7 Estimated BAF for organochlorine compounds and mercury in African penguin (Spheniscus demersus) tissues and organs

\begin{tabular}{|c|c|c|c|c|c|c|c|c|c|}
\hline \multirow[t]{2}{*}{ Compounds } & \multicolumn{3}{|c|}{8 Y 7 M } & \multicolumn{3}{|l|}{$6 \mathrm{M}$} & \multicolumn{3}{|l|}{$7 \mathrm{M}$} \\
\hline & M & $\mathrm{L}$ & B & M & $\mathrm{L}$ & B & M & $\mathrm{L}$ & B \\
\hline$\alpha$-Endosulfan & 1.1 & 0.7 & - & - & - & - & - & - & - \\
\hline Dieldrin & - & 6.8 & 8.0 & - & - & 3.3 & - & - & - \\
\hline Endrin & 1.6 & 2.6 & 21.6 & - & 0.9 & 17.7 & - & - & 12.8 \\
\hline pp'-DDT & 2.0 & 11.9 & 26.4 & - & - & 29.6 & - & 0.03 & - \\
\hline pp'-DDD & - & 10.7 & 12.7 & 2.5 & 2.5 & - & 1.3 & - & - \\
\hline pp'-DDE & 10.3 & 28.3 & 5.5 & 1.9 & 2.1 & 2.0 & 2.0 & 2.1 & 0.8 \\
\hline $\mathrm{Hg}_{\text {Total }}$ & 35.9 & 43.7 & 10.4 & 44.9 & 48.7 & 13.7 & 38.3 & 90.9 & 15.2 \\
\hline
\end{tabular}

$M$ muscle tissue, $L$ liver, $B$ brain, $8 Y 7 M 8$ years and 7 months old, $7 M 7$ months old, $6 M 6$ months old 
time, of their reintroduction into the circulation in zones of land-water contact.

Shedding old feathers and forming new plumage are considered the most effective way of eliminating toxic substances from the system. In all feathers, the concentrations of mercury, dieldrin and methoxychlor were considerably higher than concentrations in other tissues. Other insecticides, such as DDT $\mathrm{Dotal}_{\text {and }}$ its metabolites, were removed more effectively through deposition in eggs. During this process, a female, laying four eggs per year, can expel up to $20 \%$ of the insecticides introduced with food, but only up to $5 \%$ of mercury.

Chronic loading of the system with xenobiotics results in relatively low breeding success of the flock (15\%) and significant nestling mortality. The fact that a nestling lives for no more than a dozen or so days may indicate that the limit of physiological detoxification has been exceeded.

There are no accounts of lethal effects of these pollutants in the Baltic Sea. Most effects are subtle, often difficult to detect, but even if they have little influence on individuals, on chronic exposure, they can result in disorders which reduce the survival rate.

Acknowledgments The present paper was created with the financial support of the Polish Ministry of Science and Higher Education within the framework of the research project No. N N304 161637.

Open Access This article is distributed under the terms of the Creative Commons Attribution License which permits any use, distribution, and reproduction in any medium, provided the original author(s) and the source are credited.

\section{References}

Blais, J. M., Kimpe, L. E., McMahon, D., Keatley, B. E., Mallory, M. L., Douglas, M. S. V., \& Smol, J. P. (2005). Arctic seabirds transport marine-derived contaminants. Science, 309, 445.

Bond, A. L., \& Diamond, A. W. (2009a). Mercury concentrations in seabird tissues from Machias Seal Island. Science of the Total Environment, 407, 4340-4347.

Bond, A. L., \& Diamond, A. W. (2009b). Total and methyl mercury concentrations in seabird feathers and eggs. Archives of Environmental Contamination and Toxicology, 56, 286-291.

Braune, B. M. (2007). Temporal trends of organochlorines and mercury in seabird eggs from the Canadian Arctic, 19752003. Environmental Pollution, 148, 599-613.

Burger, J., \& Gochfeld, M. (1997). Risk, mercury levels, and birds: relating adverse laboratory effects to field biomonitoring. Environmental Research, 75, 160-172.
Crawford, R. J. M., Barham, P. J., Underhill, L. G., Shannon, L. J., Coetzee, J. C., Dyer, B. M., Leshoro, T. M., \& Upfold, L. (2006). The influence of food availability on breeding success of African penguins Spheniscus demersus at Robben Island, South Africa. Biological Conservation, 132, 119-125.

Donaldson, G. M., Braune, B. M., Gaston, A. J., \& Noble, D. G. (1997). Organochlorine and heavy metal residues in breast muscle of known-age thick-milled murres (Uria lomvia) from the Canadian Arctic. Arch Envirin Contam Toxicol, $33,430-435$.

Ebadi, A. G., Zare, S., \& Babaee, M. (2005). The study of measurement of residues of heptachlor (organochlorine pesticides) in the four fish species in Caspian Sea. Pakistan J Biol Sci, 8(10), 1443-1446.

El-Mekkawi, H., Diab, M., Zaki, M., \& Hassan, A. (2009). Determination of chlorinated organic pesticide residues in water, sediments and fish farms at Abbassa and Shal AlHusainia. Shakia governorate. Australian J Bass Appl Sci, 3(4), 4376-4383.

Falandysz, J., Brudnowska, B., Iwata, H., \& Tanabe, S. (1999a). Organochlorine pesticides and polichronated biphynls in the ambient air of Gdansk. Roczniki PZH, 50(1), 39-48.

Falandysz, J., Strandberg, B. L., Strandberg, P., Bergqvist, A., \& Rappe, C. (1999b). Dieldrin, aldrin, endrin, isodrin, endosulphan 1 and 2 in the fish of the Gdansk Bay. Roczniki PZH, 50(2), 131-138.

Falandysz, J., Strandberg, L., Mizera, T., \& Kalisińska, E. (2000). The contamination of the white-tailed eagle with organochlorine compounds in Poland. Roczniki PZH, 51(2), 7-13.

Falandysz, J., Strandberg, L., Puzyn, T., Gucia, M., \& Rappe, C. (2001). Chlorinated cyclodiene pesticide residues in blue mussel, crab, and fish in the Gulf of Gdansk, Baltic Sea. Environmental Science and Technology, 35, 4163-4169.

Falkowska, L., Bełdowska, M., Kwaśniak, J., Zawalich, K., \& Miotk, M. (2008). Mercury in guano from the coast of the Gulf of Gdansk. Oceanological and Hydrobiological Studies, 36(3), 98-108.

Hario, M., \& Nuutinen, J. M. J. (2010). Varying chick mortality in an organochlorine-"strained" population of the nominate Lasser Black-backed Gull Larus f. fuscus in the Baltic Sea. Ornis Fennica, 87, 1-13.

HELCOM, (2010). Hazardous substances in the Baltic Sea-an integrated thematic assessment of hazardous substances in the Baltic Sea. Balt. Sea Environ. Proc. No. 120B.

Kim, E.Y., Murakami, T., Saeki, K., \& Tatsukawa R. (1996). Mercury levels and its chemical form in tissues and organs of seabirds. Arch. Environ. Contam. Toxicol., 30, 259+266.

Kwaśniak, J., Falkowska, L., \& Kwaśniak, M. (2012). The assessment of organic mercury in Baltic fish by use of an in vitro digestion model. Food Chemistry, 132, 752-758.

Lundstedt-Enkel, K., Asplund, L., Nylund, K., Bignert, A., Tysklind, M., Olsson, M., \& Örberg, J. (2006). Multivariate data analysis of organochlorines and brominated flame retardants in Baltic Sea guillemot (Uria aalge) egg and muscle. Chemosphere, 65, 1591-1599.

Mineau, P. (2005). Direct losses of birds to pesticides - beginnings of a quantification. USDA Forest Service Gen. Tech. Rep. PSW-GTR-191, 1065-1070.

Nakao, M., Seoka, M., Tsukamasa, Y., Kawasaki, K. I., \& Ando, M. (2007). Possibility for decreasing of mercury content in 
bluefin tuna Thunnus orientalis by fish culture. Fisheries Sci, 73, 724-731.

Pearce W. (2010) Spheniscus demersus (On-line), Animal Diversity Web. http://animaldiversity.ummz.umich.edu/site/ accounts/information/Spheniscus_demersus.html. Accessed 10 Jan 2011.

Pikkarainen, A.L. (2008). Organic contaminants-occurrence and biological effects in the Baltic Sea. Doctoral dissertation. Helsinki University, Helsinki.

Polak-Juszczak, L. (2009). Temporal trends in the bioconcentration of trace metals in herring, sprat, and cod from the southern Baltic Sea in the 1994-2003 period. Chemosphere, 76, 1334-1339.

Porter, R. D., \& Wiemeyer, S. N. (1969). Dieldrin and DDT: effects on sparrow hawk eggshells and reproduction. Science, 165, 199-200.

Reindl, A. R., Bolałek, J., \& Falkowska, L. (2013). Persistent organic pollutants (POPs) in the marine food web: herrings from the southern Baltic Sea (Clupea harengus)-penguins from the zoo (Spheniscus demerus). Oceanological and Hydrobiological Studies. doi: $10.2478 / \mathrm{s} 13545$.

Rooney, J. P. K. (2007). The role of thiols, dithiols, nutritional factors and interacting ligands in the toxicology of mercury. Toxicology, 234(3), 145-156.

Sapota, G. (2006). Decreasing trend of persistent organic pollutants (POPs) in herring from the southern Baltic Sea. Oceanological and Hydrobiological Studies, 35(1), 15-21.

Schwarzbach, S. E., Stephenson, M., Ruhlen, T., Abbott, S., Page, G. W., \& Adams, D. (2005). Elevated mercury concentrations in failed eggs of the Snowy Plovers at Point Reyes National Seashore. Marine Pollution Bulletin, 50, 1444-1447.
Spalding, M. G., Frederick, P. C., McGill, H. C., Bouton, S. N., Richey, L. J., Schumacher, I. M., Blackmore, S. G. M., \& Harrison, J. (2000). Histologic, neurologic, and immunologic effects of methylmercury in captive great egrets. Journal of Wildlife Diseases, 36, 423-435.

Szefer, P., Pempkowiak, J., Skwarzec, B., Bojanowski, R., \& Holm, E. (1993). Concentration of selected metals in penguins and other representative fauna of the Antarctica. Science of the Total Environment, 138, 281-288.

Szumiło, E., Fila, G., Szubska, M., Meissner, W., Bełdowska, M., \& Falkowska, L. (2013). Mercury in the herring gull (Larus argentatus) wintering in the Gulf of Gdansk region. In L. Falkowska (Ed.) Rtęć w środowisku Identyfikacja zagrozeń dla zdrowia człowieka (pp. 109-114). Gdańsk: Fundacja Rozwoju Uniwersytetu Gdańskiego.

Usydus, Z., Polak-Juszczak, J., Bykowski, P., \& Dobrzyński, Z. (2004). The content of mercury in Baltic fish in the years 2002-2003. Chem Agric, 5, 359-367.

Vorkamp, K., Christensen, J. H., Glasius, M., \& Riget, F. F. (2004). Persistent halogenated compounds in black guillemots (Cepphus grylle) from Greenland-levels, compound patterns and spatial trends. Mar Poll Bull, 48, 111-121.

Wiener, J. G., Krabbenhoft, D. P., Heinz, G. H., \& Scheuhammer, A. M. (2003). Ecotoxicology of mercury. In D. J. Hoffman, B. A. Rattner, G. A. Burton, \& J. Cairns (Eds.), Handbook of ecotoxicology (pp. 409-463). Boca Raton: Lewis Publishing.

Whittington, P. A., Dyer, B. M., \& Klages, N. T. W. (2000). Maximum longevities of African penguin Spheniscus demersus based on banding records. Marine Ornithology, 28, 81-82.

Yin, X., Xia, L., Sun, L., Luo, H., \& Wang, Y. (2008). Animal excrement: a potential biomonitor of heavy metal contamination in the marine environment. Science of the Total Environment, 399, 179-185. 